\title{
An Oral Test in English for Chinese Non-English Major Tertiary Level Students
}

\author{
Xiaolu Xu \\ Yunnan Xinxing Occupations Institute, Yunnan Kunming, 650501 \\ Email: 1582000876@qq.com
}

\begin{abstract}
The study aims to develop items that test the speaking ability of Chinese Non-English major tertiary level students, and to develop a rating scale for the speaking test and to determine the validity and reliability of the test. Using the descriptive method, design and administer an oral test to ten randomly selected non-English major Chinese tertiary level students and find out the test can generally function as an appropriate instrument in testing the speaking ability of Chinese non-English major tertiary level students. The rating scale devised is fairly easy to handle. The test possesses face and content validity and the inter-rater reliability is high.
\end{abstract}

Keywords: English oral test, tertiary level students, assessment, communicative, reliability, validity

\section{Introduction}

It has been widely accepted that testing greatly influences instruction; and narrow testing has meant narrow instruction, teaching done "to the test" ${ }^{[1]}$.For instance, reports that after approximately 800 hours of instruction, most Chinese students "are still deaf and dumb in English". Traditional ways of testing, such as essay or multiple choice exams, can sample only a fraction of what we want to produce. Assessment must become wider ${ }^{[1]}$.

In fact, there should be an oral test in every level. However, it is even more urgent to have one in the tertiary level. For this reason, the researcher has undertaken this study. Hopefully, this will be of interest to policy-makers and administrators as well as meaningful to language teachers and language testing researchers in China.

\section{Related literature}

It has been accepted that language is more than simply a system of rules. Language is now generally seen as dynamic resource for the creation of meaning. In terms of learning, it is generally accepted that we need to distinguish between "leaning that"and "knowing how". In other words, we need to distinguish between knowing various grammatical rules and being able to use the rules effectively and appropriately when communicating ${ }^{[2]}$.

Yet all too frequently the speaking skill is more or less ignored when tests are being planned. While many teachers claim that they can assign overall grades for speaking ability according to class performance, such score are to a certain extent subjective. In addition, if all formal tests are of the pencil-and-paper variety, students will quickly realize that their preparation is most profitably spent on reading and writing. The acquisition of fluent speech habits is relegated to be status of a pleasant luxury; students no longer consider it an essential goal of the course. An oral production test at the end of the term or semester will affirm the importance of the speaking skill.

The testing of speaking is widely regarded as the most challenging of all language exams to prepare, administer, and score. For this reason, many people don't even try to measure the speaking skill. They simply don't know where to begin the task of evaluating spoken language ${ }^{[3]}$.

In his own words Weir states "To test whether learners can speak, it is necessary to get them to take part in direct spoken language activities ${ }^{[4]}$. "In terms of language assessment there are five cardinal principles to be applied: practicality, reliability, validity, authenticity, and washback ${ }^{[5]}$.

Face validity pertains to whether the test "looks valid"to the examinees, the administrative personnel and other technically untrained observers ${ }^{[6]}$.

\section{Theoretical framework}

The following theories about communicative competence/proficiency serve as bases of the researcher in the construct of the study: 


\subsection{Bachman's model of communicative language ability}

Lyle Bachman's framework of Communicative Language Ability (CLA) includes three components: language competence, strategic competence, and psychophysiological mechanisms. Language competence comprises a set of specific knowledge components that are essential in communication via language. Strategic competence is the term used to characterize the mental capacity for implementing the components of language competence in contextualized communicative language use. Psychophysiological mechanisms on the hand, refer to the neurological and psychological processes involved in the actual execution of language as a physical phenomenon (sound, light), as shown in Fig. $1^{[6]}$.

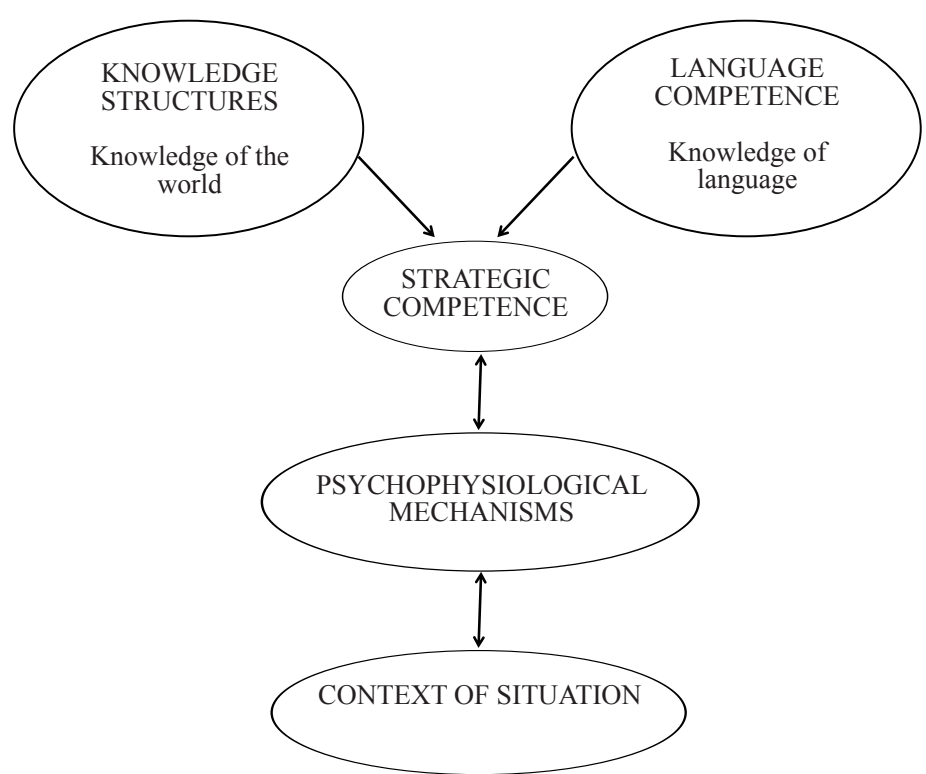

Figure 1. Components of communicative language ability in communicative language use

\subsection{Communication and the communication process}

Communication, which is a two-way process, occurs in an orderly and systematic sequence that involves giving and receiving ideas, feelings, and attitudes between two or more persons and it results in a response. In the course of speaking, the persons may exchange their roles of speaker and listener ${ }^{[7]}$.

Communication is the process of mutual interaction of people through sensory stimuli- anything that brings about a response in the nervous system, the sensory system or the feelings of a person ${ }^{[7]}$.

According to Verderber, the elements of the communication process are context, participants, messages, channels, noise, and feedback (See Figure 2) ${ }^{[8]}$.

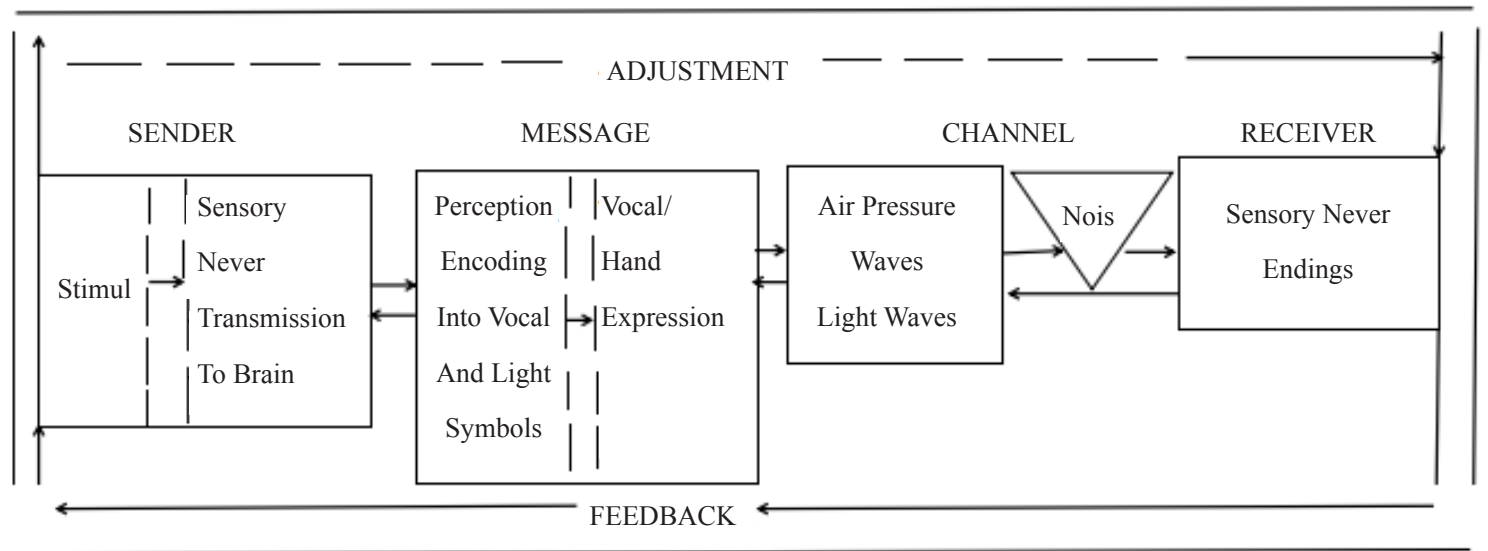

Figure 2. The process of oral communication 


\section{Methodology}

Using the descriptive method, the researcher reviewed many related literature and studies in designing and developing the oral test. The research study underwent these procedures: a) it did a survey of test types and developed a test specifications (See Table 1) b) researched extensively the cognitive and practical factors to be considered in developing and administering an oral test; c) constructed the test items based on the theoretical framework and specifications; d) showed the test items to the adviser for advice; e) revised and improved the test items; and, f) finalized the test.

Table 1. Table of specifications

\begin{tabular}{|c|c|c|c|c|c|c|}
\hline Item Type & Objectives & $\begin{array}{c}\text { Stimulus- } \\
\text { response }\end{array}$ & Scoring Scale & Test Part & $\begin{array}{l}\text { No. of } \\
\text { Items }\end{array}$ & $\begin{array}{c}\text { Time } \\
\text { Allocation }\end{array}$ \\
\hline $\begin{array}{c}\text { General } \\
\text { questions }\end{array}$ & $\begin{array}{l}\text { Make the examinee at ease, test } \\
\text { general responses }\end{array}$ & Aural-Oral & $\begin{array}{l}\text { Four-point scale } \\
\text { Four criteria }\end{array}$ & Part I & 5 & $\begin{array}{c}2-3 \\
\text { minutes }\end{array}$ \\
\hline $\begin{array}{l}\text { Sentence } \\
\text { transformation }\end{array}$ & $\begin{array}{l}\text { Test stress, intonation, structure, } \\
\text { make appropriate response }\end{array}$ & Written-Oral & $\begin{array}{l}\text { Four-point scale } \\
\text { Four criteria }\end{array}$ & Part II & 4 & $\begin{array}{c}2-3 \\
\text { minutes }\end{array}$ \\
\hline Single picture & $\begin{array}{c}\text { Identify certain specific } \\
\text { information and elaborate with } \\
\text { personal opinions }\end{array}$ & Visual-Oral & $\begin{array}{l}\text { Four-point scale } \\
\text { Six criteria }\end{array}$ & Part III & 1 & $\begin{array}{c}3-4 \\
\text { minutes }\end{array}$ \\
\hline Particular topic & $\begin{array}{l}\text { Test the ability to sustain and end } \\
\text { a topic, reasoning and critical } \\
\text { thinking }\end{array}$ & Aural-Oral & $\begin{array}{l}\text { Four-point scale } \\
\text { Six criteria }\end{array}$ & Part IV & 1 & $\begin{array}{c}3-5 \\
\text { minutes }\end{array}$ \\
\hline
\end{tabular}

The students of the test were ten randomly selected Chinese tertiary level students who were studying in the University belt of Kunming. In treatment of the data gathered, the researcher computed the mean score and total mean score of the students. The total mean scores did not show significant difference of the oral performance between the graduate and undergraduate students. She also utilized Pearson Product-Moment Correlation and got 97, 94 and 88 coefficients between the three raters, which are all high correlations. These figures indicated the test had inter-rater reliability. Furthermore, she designed a questionnaire about the test and tailed the choices as well as analyzed the tally results.

\section{Conclusion}

\subsection{Summary of findings}

In summary, the primary purpose of this study was to develop an oral test in English for Chinese tertiary level students which would test their speaking ability. Hopefully, the test would motivate the students to engage in activities practicing speaking and the teachers would spend more time on developing students' speaking skills in class.

The test items, the timing and administration generally worked well. The arrangement of giving the examinee his/ her test paper only when he/ she started that part was found effective. It was good to have more than one rater for the mean score to be near to the examinee's true rating. The scoring system proved relatively easy to handle. The inter-rater reliability of the test is high.

\subsection{Conclusions}

In light of the above mentioned findings, the following conclusions are drawn:

The test can generally function as an appropriate instrument in testing the speaking ability of Chinese tertiary level students.The rating scale devised is fairly easy to handle, although certain improvements can be done.The test possesses face and content validity and the inter-rater reliability is high.

\subsection{Recommendations}

Based on the findings and conclusions of the study, the following recommendations are proposed:

Since the test could provide diagnostic feedback indicating the examinee's weaknesses in speaking English, the information may be used for remedial instruction.Examiners should be trained before administering the test, not only about testing procedure, but also the rating.More oral tests be developed to inspire students to improve their speaking ability. 


\section{References}

[1] Pahl C. A. Develop, Not Judge Continuous Assessment in the ESL Classroom. English Teaching Froum. 1997; 35: 2.

[2] Nunan, D. Desighing Tasks for the Communicative Classroom. England: Cambridge Language Teaching Library; 2001.

[3] Madsen, H. S. Speaking Tests in Techniques in Testing. London: Oxford University Press; 1983.

[4] Weir, C. Testing spoken interaction in Understanding \& Developing Language Tests. Phoenix ELT; 1993.

[5] Douglas, B. H. Language Assessment: Principles and Classroom Practice. San Francisco State University; 2004.

[6] Bachman, L. F. Fundamental considerations in language tesing. New York: Oxford University Press; 1990.

[7] Flores, C. S. et al. Oral Communication in Effective Speech Communication. 4th ed. National Book Store; 2003.

[8] Verderber, R. F. Communicate. 9th ed. Wadsworth: An International Thomson Pub. Co; 1999. 